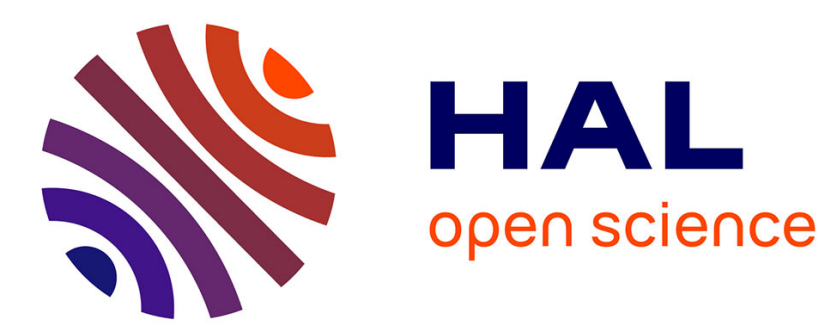

\title{
Reading Colophons from Mesopotamian Clay-tablets Dealing with Mathematics
}

\author{
Christine Proust
}

\section{To cite this version:}

Christine Proust. Reading Colophons from Mesopotamian Clay-tablets Dealing with Mathematics. NTM Zeitschrift für Geschichte der Wissenschaften, Technik und Medizin, 2012, pp.123-156. hal01139636

\section{HAL Id: hal-01139636 \\ https://hal.science/hal-01139636}

Submitted on 7 Apr 2015

HAL is a multi-disciplinary open access archive for the deposit and dissemination of scientific research documents, whether they are published or not. The documents may come from teaching and research institutions in France or abroad, or from public or private research centers.
L'archive ouverte pluridisciplinaire HAL, est destinée au dépôt et à la diffusion de documents scientifiques de niveau recherche, publiés ou non, émanant des établissements d'enseignement et de recherche français ou étrangers, des laboratoires publics ou privés. 


\title{
Reading Colophons from Mesopotamian Clay-tablets Dealing with Mathematics
}

\author{
Eine Betrachtung von Kolophonen mathematischen Inhalts auf mesopotamischen \\ Tontafeln
}

\section{Christine Proust}

To appear in NTM Journal of the History of Science, Technology and Medicine

\begin{abstract}
Kolophone sind kurze Vermerke, die manchmal am Rand von Keilschrifttexten zu finden sind. In ihnen sind Angaben zum Text und dessen Verarbeitung, insbesondere der Tontafeln, zu finden und sie geben damit Aufschluss über den Zusammenhang, in dem die Dokumente erstellt worden sind. Im Beitrag werden am Beispiel altbabylonischer mathematischer Texte die Beziehungen zwischen der Zusammensetzung von Kolophonen, der Art von Tafeln, die sie enthalten und dem Inhalt der Texte, denen diese Kolophone hinzugefügt worden sind, untersucht. Dabei werden zuerst die Probleme diskutiert, die durch die Klassifizierung des uns vorliegenden mathematischen Materials aus Mesopotamien entstanden sind. Das zweite Ziel besteht darin, die Funktion einiger ausgewählter Texte - in erster Linie Kataloge und Serien - zu klären und nachzuweisen, dass die Absichten ihrer Autoren vielfältiger gewesen sein konnten als allgemein angenommen wird, indem sie Erfindung, Systematisierung, Klassifizierung, Konservierung und Lehre gedient haben.
\end{abstract}

Keywords: mathematical cuneiform texts, colophon, catalogue, series texts, classification. Schlüsselwörter: mathematische Keilschrifttexte, Kolophon, Katalog, Serie, Klassifizierung

In the first millennium BCE Mesopotamian scribes used to add highly developed colophons to their works, especially when writing scholarly texts, for example, on medicine, divination or astral sciences. This kind of postscript, often located at the end of the text, provides modern historians with a plethora of information relative to the scribe who wrote the text, the place where he composed it, the content of the composition, the original document copied (if any), and the owner of the tablet. Other writing practices are particularly remarkable, such as noting long compositions on series of dozens of numbered tablets, in the same way as we number the pages of a book. These practices reflect a very specific context of that time: that of the creation, enrichment, management and maintenance of large libraries. Organization into series, the presence of colophons, as well as the existence of catalogues, are considered as the three criteria for determining that a set of documents comes from a library (Clancier 2009: 13). ${ }^{1}$

In the Old Babylonian period (circa 2000-1600), colophons and series texts were not widespread, at least as far as we can judge from surviving documents. However, these forms are attested in some specific contexts to be analysed in detail. In this article I will focus on colophons found in Old Babylonian mathematical texts. I do not intend to inventory and describe all these colophons, but rather to analyze the relationship between the colophons and other features of the documents in which they appear. ${ }^{2}$ Indeed, such a relationship may provide some answers to important questions concerning the mathematical practices in the 
Old Babylonian period: To whom were the texts addressed and what was their purpose? In secondary literature, the answer to these questions is generally that the mathematical cuneiform texts reflect teaching practices developed in the scribal schools. Nonetheless, I will show that the practices involved may have been more diverse.

The first important observation is that there is a strong relationship between the colophons, and certain categories of mathematical texts such as catalogues (lists of problem statements) and series texts (lists of problem statements written on numbered tablets). ${ }^{3}$ To analyze this relationship closely we have to discuss what is meant by "category of texts". This question is part of the more general problem of the classification of ancient mathematical material by modern historians. Unfortunately, the current classifications do not benefit from a strong consensus among specialists. My aim is not to establish a new classification, but rather to address more limited issues, using the information provided by the colophons. First, I approach the problem of classification as a practice carried out by the scribes themselves. Second, I identify some relevant groups of documents, each of which should be considered as relating to a particular kind of mathematical practice.

In the following, I first provide some background information on mathematical cuneiform texts, examining the physical aspects of the tablets and the content of the texts. In the second part, the relationship between the colophons and other physical and textual aspects, as described in the first part, will be analyzed. The two subsequent sections focus on the catalogues, and then on the series texts. The analysis mainly concerns the structure of the lists of statements in such texts, and the identification of the operations on texts, which produced these lists (extraction, compilation, concatenation). The final discussion emphasizes the diversity of the intellectual projects testified by Old Babylonian mathematical texts. Some of these projects seem to be closely related to teaching tasks, while others seem to show an intention to classify, archive or create new materials.

\section{COLOPHON, TEXT AND TABLET}

Most of the known cuneiform mathematical texts were produced during the Old Babylonian period. ${ }^{4}$ The majority of the mathematical tablets come from illicit excavations carried out in Iraq by the late nineteenth and early twentieth century. About seventy percent of the known Old Babylonian mathematical documents are elementary school tablets, produced by young students during the early stages of their education. This educational material is easy to identify as the physical appearance of the tablets and their content are quite stereotyped. ${ }^{5}$ However, the authors, audience and scope of the other mathematical documents are far from clear. Let me designate mathematical documents that were not produced as part of elementary education as "advanced". The advanced texts may have been written by already well-educated students, masters or scholars. This very broad classification of mathematical material between elementary and advanced texts roughly corresponds to the classification made by Neugebauer into table-texts and problem-texts (Neugebauer 1935-1937, I: 2, Neugebauer/Sachs 1945: 1). The distinction between elementary and advanced mathematics refers to ancient practices in scribal schools and is quite evident for any observer of cuneiform mathematics. Much more difficult and controversial is the 
classification of advanced mathematical texts. Before coming back to this problem, let us examine the physical appearance of the documents.

The typology of tablets containing school exercises is characteristic of the teaching context, and the relationship between the educational use of the tablets and their shape has been studied at length (Veldhuis 1997). In contrast, the shapes of the tablets containing advanced mathematics are not so clearly correlated to their provenance, dating, content and use as is the case for school tablets. However, in the particular case of literary tablets from Nippur, it seems that there is a relationship between the function of the tablets and the organisation of the text they contain, notably the number of columns. Tinney 1999 differentiated single column (type $S$ ) and multicolumn (type $M$ ) tablets. ${ }^{6}$ The type $S$ tablets were used in the intermediate level of education, immediately following the elementary one. The type $M$ tablets (I note $\mathrm{M}(\mathrm{m} / \mathrm{n})$ a tablet with $m$ columns in the obverse and $n$ columns in the reverse) seem to have been used for more diverse purposes, including advanced learning, exams and erudition. ${ }^{7}$

As elementary school material is profuse, often of known origin, and has been thoroughly studied in recent years, the classification of texts made by historians is quite clear. This classification came about in a fairly natural way from the reconstruction of the elementary curriculum. Indeed, during their elementary education, the young scribes learnt not only some basic notions, but also the structure and order of the texts providing this knowledge. Thus, the categories of texts - metrological lists, metrological tables, numerical tables reflect the curriculum. ${ }^{8}$ One can assert that, in this case, the categories used by present-day historians follow quite closely the categories - if not, at least, the practices - of ancient actors.

Categorizations of advanced mathematical texts have been proposed in different ways by several historians. Among the so-called problem-texts $\mathrm{H} \varnothing$ yrup (2002: 9) distinguishes anthologies, which bring together problems relating to several different topics, and so-called theme-texts that assemble problems related to the same topic. Among the theme-texts, he identifies the catalogues and the series texts as follows: "Theme texts may be either catalogue texts listing only problems statements, or procedure texts. A particular kind of theme texts are the series texts, texts that occupy several tablets which together make up a series - mostly written in utterly elliptic logographic writing." [Emphasis in the original] This classification resulted from the long collaboration between $\mathrm{H} \varnothing$ yrup and Friberg (ibid.: 8, footnote 13). Robson 1999 (6-8) suggests another classification with four categories: problem-texts, coefficient lists, catalogues, and rough work. ${ }^{9}$ In my view, all these classifications raise the same problem: it is not clear if the categories were defined by various modern authors in order to organize their own work, or in order to illuminate different ancient practices.

As already mentioned, the objective of my article is not to discuss a general classification of mathematical material from Mesopotamia-perhaps an impossible task given the variety of mathematical traditions involved-but rather to point out some groups of documents deserving to be studied together. Such sets may bear witness to specific and recognizable mathematical practices. My starting point is the idea that the observation of colophons, in 
relation to other features of the texts and tablets, may help to select these sets of documents.

\section{THE COLOPHONS}

Old Babylonian colophons are much less systematic, codified, and informative than they are in the first millennium. In the mathematical documents, colophons are generally placed at the bottom of the reverse of a tablet, and are separated from the main text by a blank space, a single line or a double line. The colophon can also be located on an edge of the tablet. Some additional information is sometimes included in the text itself. This is the case, for example, for catchlines, ${ }^{10}$ incipits, or labels. In some cases a doxology introduces a text. ${ }^{11}$

To this date there exists no comprehensive study of Old Babylonian colophons, but some studies of colophons attached to specific genres of texts are available. ${ }^{12}$ Robson (1997: 58; 67-70) has compiled a list of mathematical tablets, published before 1945, containing colophons, and she classified these tablets into four groups according to the composition of their colophons. The data used in the present study comes from the inventory collected by Robson in 1997, as well as from sources published after 1945 (Friberg 2000, 2007, Robson 2008, Proust 2007, 2009).

The colophons may contain different kinds of components. The presence of a date, a proper name, a doxology or a catchline is documented mainly in elementary school tablets. ${ }^{13}$ Some exceptions to this rule are known, ${ }^{14}$ but these tablets are quite disparate and their origins remain unclear. Thus, any analysis of their colophon does not provide much information about mathematical practices in a specific milieu. Another important component of colophons is what one might call a "title" or a "label", that is, a key word or short phrase that indicates the content of the text to which the colophon is attached. The label may also be included in the text, as an incipit or as an entry of the items, or noted in a postscript. These labels appear mainly in catalogues. ${ }^{15}$ Other components of the colophons can be the number of items such as lines ( $\mathrm{m} \mathrm{u}$ ), procedures (kibsu) or sections ( $\mathrm{i} m-\mathrm{s} \mathrm{u}$ ). The existence of a Sumerian and Akkadian ${ }^{16}$ vocabulary designating different segments of text is of historical importance in itself.

The number of lines $(\mathrm{m} \mathrm{u})^{17}$ is mentioned only in a few mathematical tablets for counting lines in colophons or heading. ${ }^{18}$ Each of the tablets containing a count of $\mathrm{m}$ u presents particular features that are not found in other mathematical tablets, and they do not form a homogeneous set. Thus, the presence of the term $\mathrm{m} \mathrm{u}$ does not seem to provide a relevant criterion for identifying a category of texts. In five tablets of unknown origin, the colophon indicates the number of kibsu. These five tablets were classified by Goetze 1945 and Høyrup 2002 (chapter 9) into groups that belong to traditions developed in central Mesopotamia, possibly in Sippar, and probably date from the late Old Babylonian period. This set is very homogeneous, and may be a reflection of the local way of writing mathematical texts. One could hypothesize that, in the milieu where these five texts were written, the "procedure texts" (kibsu) were explicitly identified as a particular category of texts.

The term i m - š u literally means "hand tablet". In some literary texts, this term is used to designate small round or square tablets containing a school exercise. The term occurs in 
colophons of mathematical texts, where it designates either a section, namely a space on the tablet bounded by vertical and horizontal lines, or the content of a section, namely the statement of a problem. In fact, the number of sections and the number of statements do not always coincide. For example, in series texts, when a line section between two statements is omitted, there are more statements than sections; conversely, when a change of column comes in the middle of a statement, there are more sections than statements. The scribes sometimes counted sections, and sometimes counted statements. ${ }^{19}$

We now have enough information to examine the relationships between the colophons, typology of tablets and content of the texts. From the previous considerations and from the inventory of catalogues and series texts given in the Tables A, B and C in Appendix 1, we may draw some correlations. ${ }^{20}$

Of the 24 tablets providing the number of the sections, five contain catalogues, sixteen contain series, and only two contain procedures. Conversely, among the thirteen catalogues, six contain the number of the sections (and three are uncertain); of the twenty series tablets, sixteen contain the number of the sections. The majority of the tablets listed in Table A of Appendix 1 (catalogues) are of type S; all the tablets listed in Table C of Appendix 1 (series) are of type $M$. The approximate correlations mentioned in the previous sections are very roughly summarized in Table 1.

\begin{tabular}{|l|l|l|l|l|l|}
\hline Colophon & $\begin{array}{l}\text { Type of } \\
\text { tablet }\end{array}$ & Language & Provenance & Collection ${ }^{21}$ & $\begin{array}{l}\text { Category of } \\
\text { text }\end{array}$ \\
\hline $\begin{array}{l}\text { Number of } \\
\text { sections } \\
+ \text { label }\end{array}$ & $\mathrm{S}$ & Sumerian & $\begin{array}{l}\text { Unknown } \\
\text { (Southern } \\
\text { Mesopotamia?) }\end{array}$ & YBC & Catalogues \\
\hline $\begin{array}{l}\text { Number of } \\
\text { sections } \\
+ \text { serial } \\
\text { number }\end{array}$ & $\mathrm{M}$ & Sumerian & $\begin{array}{l}\text { Unknown } \\
\text { (Central } \\
\text { Mesopotamia?) }\end{array}$ & $\begin{array}{l}\text { Mainly YBC } \\
+ \text { AO, VAT, OI }\end{array}$ & Series texts \\
\hline $\begin{array}{l}\text { Number of } \\
\text { procedures } \\
\text { (kibsu) }\end{array}$ & $\mathrm{M}$ & Akkadian & $\begin{array}{l}\text { Unknown } \\
\text { (Central } \\
\text { Mesopotamia, } \\
\text { Sippar?) }\end{array}$ & $\begin{array}{l}\text { Mainly BM } \\
+ \text { VAT }\end{array}$ & $\begin{array}{l}\text { Procedure } \\
\text { texts }\end{array}$ \\
\hline $\begin{array}{l}\text { Number of } \\
\text { lines }\end{array}$ & various & Akkadian & various & various & various \\
\hline
\end{tabular}

Table 1: Colophon, Type of Tablets and Categories of Texts in Old Babylonian Advanced Mathematics

Thanks to these observations, several groups of tablets can be discerned. Tablets of known provenance (Susa and the kingdom of Ešnunna) reveal specific practices and deserve special examination in relation to archaeological data; this will not be undertaken in this article. Among tablets of unknown provenance, three homogeneous groups emerge from the observation of the colophons: the catalogues kept at Yale, the series texts kept at Yale, Chicago, the Louvre and Berlin, and the procedure texts "kibsu". I focus on the two former. 


\section{CATALOGUES}

Some features of the catalogues in the Yale Babylonian Collection have already been mentioned: these lists of statements are in most cases accompanied by a colophon indicating the number of sections, and, sometimes, the theme of the list (label). Moreover, they are usually written on type $S$ tablets. Another interesting feature already indicated is the language. All the catalogues use almost exclusively Sumerian ideograms. Moreover, some elements of Sumerian grammar such as verbal prefixes and case suffixes are noted. In some tablets (C5 through C8 - see Appendix 1), the Sumerian terminology is particularly rich. Conversely, in the tablets from Susa as well as those from northern Mesopotamia (IM 52916+, IM 52672, BM 80209), the texts are written in Akkadian.

By analyzing the textual structure of the Yale catalogues I highlight specific textual operations, which result from a particular intellectual project. The examples studied are extracted from catalogues C3, C4, C7, C8, C5 and related texts. My goal is twofold. First, this selection exemplifies the main features of catalogues. Second, the analysis of text $\mathrm{C} 5$ and related procedure texts illuminates how the scribes composed these catalogues by means of compilation. Thus, the significance of the colophons and the function of the catalogues will become clearer.

\section{C3 (YBC 4607)}

What makes tablet C3 so interesting is that it provides basic terminology and methods for elementary mathematics, namely the calculation of volumes. Moreover, the systematic organisation of the text sheds light on the mechanism used by the scribes for building lists. Tablet C3, of type S, contains ten statements concerning the dimensions of different models of bricks. The number of sections ( $10 \mathrm{im}-\mathrm{s} u-\mathrm{m}$ e š) is noted on the left edge, ${ }^{22}$ so the colophon here is clearly separated from the main text (see figure 1 ).

[to the publisher: Please insert Figure 1: "Fig. 1: Colophon of Tablet C3: left edge (copy Neugebauer, Neugebauer/Sachs 1945: Plate 12)]

The statements are written in Sumerian, except for one Akkadian term used to describe the layer of bricks (taddītum). ${ }^{23}$ All ten statements form a highly structured group. Statements begin with the name of a brick format, that is, the ratio width/length. These ratios are

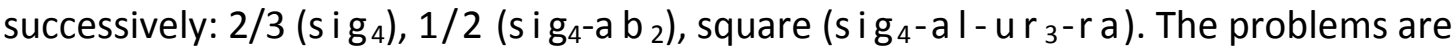
divided into two groups according to the nature of the data (see the first column of Table 2 below). Then the bricks in each group feature consecutively those three formats, and for each format, the bricks have one or two different sizes. The statements noted in the first group (\#1-\#5) show the same pattern (Neugebauer/Sachs 1945: 92): ${ }^{24}$

$\# 1$

A brick. $1 / 2$ kuš 3 is its length.

$1 / 3$ kuš $_{3}$ is its width, 5 šu-si its height.

What are the area, its volume, and oil, the equivalent of its volume ${ }^{25}$ ?

10 še (and) one-half še is its area; 2 še and one twelfth še is its volume; $1 / 3 \mathrm{sila}_{3}$ (and) $81 / 2 \mathrm{gin}_{2}$ oil is the equivalent of its volume. 
The statements noted in the second group (\#6-10) show the same pattern (ibid.: 92):

\section{\#6}

A brick. $1 / 2$ kuš 3 its length, $1 / 3$ kuš 3 its width,

5 šu-si its height. [How] much laying (of bricks) [did] 1 sar area [take]?

It took 1 sar (and) $2 \times 60+24$ (bricks)

In this way, the five standard types of bricks used in mathematical texts are reviewed.

[please insert Table 2: "Table 2: Structure of Catalogue C3"]

The structure of this list shows some typical features of mathematical lists, based on a cyclic permutation of the parameters of the problems. This method allows the author of the text to review all possible cases and to provide the basic toolbox for volume calculations. This toolbox includes the following mathematical elements: use of metrological tables of lengths, heights, areas and capacities; expression of the volume in the three systems: standard units, the number of bricks, and capacity in the equivalent liquid; knowledge of the standard models of bricks.

This text can thus be read as a reference table that provides all the relevant information on the metrological systems used in mathematics during the Old Babylonian period in order to calculate volumes, including a complete description of the standard bricks used as units. ${ }^{26}$ The colophon states "10 sections" (10 i m - š u - m e š), and all the statements start with the label "bricks". The meaning of this kind of paratextual information may be "all about brickvolumes in ten sections". Text C3 appears to be a systematic list of "formulae" resulting from teaching practices.

\section{C4 (YBC 4652)}

The appeal of Text C4 lies in the fact that the structure of the statements reflects the structure of the expected method of resolution, although the procedures are not explicitly stated. Tablet $\mathrm{C} 4$, of type $\mathrm{S}$ with very rounded edges, originally contained 22 statements, only eight of which are preserved. All the statements start with the label "stone" ( $\left.n \mathrm{a}_{4}\right)$. The number of sections (22 [im-š u $\left.n a_{4}(?)\right]$ ) is noted at the end of the text after a double line and a blank space (see figure 2).

[please insert figure 2: “Fig. 2: Colophon of Tablet C4: end of the reverse (copy Neugebauer, Neugebauer/Sachs 1945, Plate 13)]

The statements relate to different variants of a fanciful story about a stone, whose initial weight is unknown, and which is broken repeatedly. The text is written in a quite well developed Sumerian language, containing grammatical complements and an extended glossary. No Akkadian terms are used. From a modern mathematical point of view, the text deals with linear problems that raise two issues: the coefficients are fractional and the resolution requires several changes of variables. ${ }^{27}$ All the problems lead to a single basic pattern: find a number knowing the sum (or the difference) of this number and a fraction of this number. We would note them in modern language as follows:

$x+1 / \mathrm{N} x=\mathrm{M}$ 
or

$x-1 / \mathrm{N} x=\mathrm{M}$,

where $\mathrm{M}$ and $\mathrm{N}$ are known integers chosen so that the solution is a simple number. In fact, the problems are much more complex than the pattern indicated above. The main difficulty is reducing the problems to the basic pattern. ${ }^{28}$ The succession of statements \#8 and \#9 clarifies the way in which the procedure of reduction is suggested. The translation of statements \#8 and \#9 (Neugebauer/Sachs 1945: 101) reads as follows:

\#8

I found a stone, (but) did not weigh it; (after) I subtracted one-seventh (and) subtracted onethirteenth,

I weighed (it): 1 ma-na. What was the original (weight) of the stone? The original (weight) of the stone was 1 ma-na (and) 15 5/6 gin $_{2}$.

\#9

I found a stone, (but) did not weigh it; (after) I subtracted one-seventh, added oneeleventh $^{29}$ (and)

subtracted one-thirteenth, I weighed (it): 1 ma-na. What was the original (weight) of the stone? The original (weight) of the stone was $91 / 2$ gin $_{2}$ (and) $21 / 2$ še.

The variant introduced in \#9 adds new fractioning (I added one-eleventh). This formulation is defective and means: I added (to the expression previously obtained) one-eleventh (of the expression previously obtained) (ibid.: 102).$^{30}$ This variant suggests that the resolution of the problem stated in the section 9 required the resolution of the simpler problem stated in section 8 . This process of reduction could be schematized as follows:

\#8

Weight of the stone, unknown $(\mathrm{k})$

$1 / 7$ of the expression previously obtained $(k)$

$\mathrm{k}$

Subtract $1 / 7$ from $k$ (I note the result $P$ )

$1 / 7 \mathrm{k}$

$1 / 13$ of the expression previously obtained $(P)$

$\mathrm{k}-1 / 7 \mathrm{k}=\mathrm{P}$

Subtract $1 / 13 P$ from $P$

$1 / 13 P$

Result of the final weighing: 1 ma-na

$P-1 / 13 P$

\#9

Weight of the stone, unknown (k)

$P-1 / 13 P \rightarrow 1$ ma-na

$1 / 7$ of the expression previously obtained $(k)$

$\mathrm{k}$

Subtract $1 / 7 \mathrm{k}$ from $\mathrm{k}$ (I note the result $\mathrm{P}$ )

$1 / 11$ of the expression previously obtained $(P)$

$1 / 7 \mathrm{k}$

Add $P$ and $1 / 11 P$

$1 / 13$ of the expression previously obtained (S)

$k-1 / 7 k=P$

1/11 P

Subtract $1 / 13 \mathrm{~S}$ from $\mathrm{S}$

$P+1 / 11 P=S$

$1 / 13 \mathrm{~S}$

Result of the final weighing: 1 ma-na

$S-1 / 13 S$

$S-1 / 13 S \rightarrow 1$ ma-na

One could easily infer that the previous statement of the sequence (\#6 or \#7, destroyed) was limited to the first three lines of \#8, that is to say, to the basic pattern: "find the weight knowing the sum (or the difference) of this weight and a fraction of this weight". So, the required resolution process would be the following:

for \#6 or 7: find k; 
- $\quad$ for \#8: find $P$; knowing $P$, find $k$;

- $\quad$ for \#9: find $S$; knowing $S$, find $P$; knowing $P$, find $k$.

The text, through the successive statements, suggests the reader to use a reduction method by changing the unknown. Thus, although the text does not contain the procedures, it indirectly gives quite accurate information as to what these procedures might be.

To summarize, catalogue $\mathrm{C} 4$ focuses on linear problems involving fractions. Its structure is related to the nature of mathematical tools required for solving the problems. Although part of the text is lost, the preserved sections show an increasingly complex progression. Step by step, a method for solving complex linear problems is built with successive reductions. Therefore, the text seems to have a strong thematic and mathematical coherence. The thematic unity of the text is underlined by the presence of the label "stone" (na $\left.\mathrm{a}_{4}\right)$ in each entry. The colophon is not entirely preserved, but we can guess that the label "stone" might appear in the colophon, in the same way as the label "trench" appears in colophon of C7.

Whereas the list of statements on C4 is mathematically coherent and thematically homogeneous, the following three samples illustrate other configurations: these texts appear to be composite. By analyzing texts $\mathrm{C} 7$ and $\mathrm{C} 8$, I will show that catalogues are often made up of different groups of statements. Text $\mathrm{C} 5$ and related procedure texts shed light on the nature of textual operations leading to such compositions.

\section{C7 (YBC 4666) AND C8 (YBC 7164)}

The samples C7 and C8 (as well as C5 studied in the next section) are related to the digging of an excavation (a canal or a trench). The parameters are the dimensions of the excavation (length, width, depth), the base area, the total volume of earth excavated, the daily work (volume of earth excavated per worker per day), the daily wage, the number of working days, the number of workers and the total cost.

Tablet $\mathbf{C 7}$, of type $\mathrm{S}$, contains a list of 23 statements on the digging of a canal by workers and the cost of this work. All the statements are introduced by the label "canal" ( $\mathrm{pa}_{5}-\mathrm{sig}$ ) or "cost of the canal" ( $\left.k u_{3} \quad \mathrm{pa}_{5}-\mathrm{sig}\right)$. A colophon inscribed on the left edge indicates "26 sections on canal" (26 i m-š u pa ${ }_{5}$-sig) (see figure 3 ). This count does not correspond to the actual 23 sections. I will return to this interesting discrepancy later.

[to the publisher: please insert Figure 3: "Fig. 3: Colophon of Tablet C7: left edge (copy Neugebauer, Neugebauer/Sachs 1945: Plate 9)]

In the first sections, the shape of the canal is a prism, and in the subsequent sections, several enhancements to the profile of the canal are made. In sections \#12 and \#13 the canal is deepened; in \#14 through \#23 the sidewalls are inclined; and in \#22 and \#23 the calculation of the slope of the sidewalls is introduced. The catalogue is thus composed of five groups summarized in Table 3:

[please insert Table 3: "Table 3: Groups in Catalogue C7"] 
The list of statements is not as homogeneous as in the previous samples (C3 and C4). The text is composed of several groups related to different mathematical situations. For example, wages are expressed in terms of capacity of grain in $\# 1$ to $\# 13$, but in terms of weight of silver in \#14 to \#23; the canal is a prism (vertical sidewalls) in the first and last statements (\#1-\#3, \#23), but a trapezoidal prism (inclined sidewalls) in the rest. The sequence of statements in the first group (\#1-\#8) suggests the method of solving problems as in the catalogue on stone $\mathrm{C} 4$ : each statement improves on the previous one, and solving each problem requires following all the steps that were required for the previous one. The same applies for texts in the fourth group (\#14-\#20).

The last statement is incomplete: only the data is present, but neither the question nor the answer is given (see text below). According to Neugebauer/Sachs (1945: 81), the last statement is a kind of catch line, which connects $C 7$ with another tablet; this latter could be catalogue C8 (YBC 7164). Indeed, the end of C7 and the beginning of C8 are identical, as shown below (ibid.: 79, 82):

\section{C7 (YBC 4666), \#23}

A little [canal]. 5 UŠ is the length, 3 kuš 3 is the width, 3 kuš ${ }_{3}$ its depth, 10 gin $_{2}$ [(volume) the assignment],

[6] še (silver) the wages of a hired man.

\section{C8 (YBC 7164), \#1}

A little canal. 5 UŠ is the length, 3 kuš 3 is the width, 3 kuš 3 its depth, [10 gin ] (volume) the assignment,

6 še (silver) the wages of a hired man. What are the area, the volume, the (number of) workers, the (total expenses in) silver?

1 (geš) 15 sar is the area; <2>(iku) 25 sar is the volume; 2(gešu) 2(geš) 30 is the (number of) workers; [and 2/3] ma-na 5 g in $_{2}$ is the (total expenses in) silver.

However, one detail raises doubt as to whether the final statement of $\mathrm{C} 7$ is a catchline. This detail is the discrepancy between the number of statements actually recorded on the tablet (23 sections) and the number reported in the colophon (26 sections). The colophon, which may have been written in advance, suggests that the scribe intended to write 26 statements, that is, the 23 existing and three other statements. But when reaching the end of the tablet, the scribe seems to have run out of space. We have before us a case where the tablet is complete, but not the text that the scribe had planned to write on it. Since we find the content of section 23 again at the beginning of catalogue $\mathrm{C} 8$, it is likely that the work undertaken by the author of tablet $\mathrm{C} 7$ continued with the writing of tablet $\mathrm{C} 8$. But the shift between $\mathrm{C} 7$ and $\mathrm{C} 8$ was not planned. Nothing indicates that the same scribe wrote both tablets $\mathrm{C} 7$ and $\mathrm{C} 8$. Some epigraphic differences suggest the opposite. For example, the name of the length unit is noted GAR.UŠ in $\mathrm{C7}$ and UŠ in $\mathrm{C}^{31}$. Anyway, the author of tablet $\mathrm{C} 8$ seems to have abandoned the project started by the author of tablet $\mathrm{C} 7$ after writing the first statement, as shown by the following examination of catalogue $\mathrm{C} 8$.

Tablet C8, of type S, contains a list of 18 statements concerning the digging of a canal by workers and the cost of this work. All the statements are introduced by the label "canal" $\left(\mathrm{pa}_{5}\right.$-sig). The tablet ends with a double line followed by a blank space and does not bear a 
colophon. The first statement seems isolated and closer to those in catalogue C7 than to the other statements of $\mathrm{C} 8$. Other problems consider different situations that complicate the problems related to canals. In the first group of statements, the daily work varies with the depth of the canal. In the second group, the canal is widened. In the third, the canal is both broadened and deepened. The mathematical content is similar to the previous one: phased single and double proportionality elements and no quadratic problems. The introduction of variable daily work requires the use of weighted averages to solve the problems.

Texts $\mathrm{C7}$ and $\mathrm{C} 8$ are representative of catalogues. Statements dealing with the same theme are brought together on the tablet. The common theme is represented by a label, which appears in the entry of the statements and again in the colophon. In some cases, such as C3 and C4 cited above, the list of statements forms a strongly coherent set. However, in the majority of catalogues known to date, the list is composed of several groups dealing with different mathematical topics. Tablet C5, presented in the following, provides some explanations of this phenomenon.

\section{C5 (YBC 4657) AND RELATED TEXTS}

Tablet $\mathrm{C} 5$, of type $\mathrm{S}$, contains a list of 31 statements about the digging of a trench by workers and the cost of this work. All the statements are introduced by the label "trench" $\left(\mathrm{k}-\mathrm{I} \mathrm{a}_{2}\right)$, "cost of the trench" $\left(\mathrm{ku}_{3} \mathrm{ki}-\mathrm{I} \mathrm{a}_{2}\right)$ or "volume of earth excavated" (s a har ki-l $\left.\mathrm{a}_{2}\right)$. The number of sections of the tablet is noted on the upper edge at the end of the text after a double line where we read "31 sections on trenches" (31 i m - š u ki - I a $a_{2}$ ); see Figure 4. Here, the label "trench" $\left(\mathrm{ki}-\mathrm{I}_{2}\right)$ appears at the beginning of the statements, and again in the colophon. As before, this label underlines the thematic homogeneity of the list.

[to the publisher: please insert Figure 4: "Fig. 3: Colophon of Tablet C5: upper edge (copy Neugebauer, Neugebauer/Sachs 1945: Plate 6)]

Although catalogue C5 uses the same scenario as catalogues C7 and C8, several differences are notable. The geometrical situation is simpler than the previous ones, since the basic shape of the excavation is a prism in all the sections, but the mathematical notions include quadratic problems. Catalogue $\mathrm{C} 5$ is composed of several groups of problems. The statements in sections \#1 to \#8 form the first homogeneous group. In section 1 , the statement gives the dimensions of the trench (length, width and depth), the daily work and the daily wages. The base area, the volume of earth excavated, the number of workers, and the total cost are requested. In sections \#2 to \#6, the statements are generated by cyclic permutations of these parameters. All these problems can be solved by using a succession of multiplications and divisions. In sections \#7 and \#8, the data concerns the sum (or difference respectively) of the length and the width, and leads to quadratic problems.

The statements in sections \#9 to \#18 form the second homogenous group. The trench has the same dimensions as in the previous group, but there is no mention of wages. In section \#9 the statement gives the dimensions of the trench, and requests the base area and volume of the excavated earth. In sections \#10 to \#13 the statements are generated by the cyclic permutations of the parameters given in section \#9; the problems could be solved by a succession of multiplications and divisions. Sections \#14 to \#18 contain quadratic problems: 
in \#14, volume, depth, and the sum of the length and the width are given; sections \#15 to $\# 18$ include the sum of the base area and the volume as well as, one after the other, length, width, depth, and the difference between length and width. This appears to be an important novelty: the fact that some data refers to the sum of non-homogeneous magnitudes (area and volume).

The statements in sections \#19 to \#28 form the third homogeneous group. The parameters are the dimensions of the trench (always the same), and data concerning the work (the daily work, the daily wages, the number of working days, the total cost). All the problems deal with proportionality and can be solved by a succession of multiplications and divisions. The last three problems are isolated. The dimensions of the trench are changed in the last problem. In brief, this catalogue forms a thematically coherent set, since all the statements are related to trenches $\left(\mathrm{ki}-\mathrm{I}_{2}\right)$, and the dimensions of the trench are the same (except for the last statement). However, the different groups do not relate to the same mathematical skills (see Table 4 below).

Two other tablets provide explanations for the presence of several groups of statements in the catalogues. In the Yale Babylonian Collection Neugebauer and Sachs (1945) found two tablets containing the resolutions to some of the problems given in catalogue C5. Tablet YBC 4663 (referred to as $\mathrm{P} 5 \mathrm{a}$ in the following) contains eight problems; the statements reproduce exactly the first group in catalogue $\mathrm{C} 5$, and each of them is followed by the resolution procedure. Tablet YBC 4662 (referred to as P5c in the following) contains nine problems; the statements reproduce exactly the third group of catalogue $\mathrm{C} 5$, and each of them is followed by the resolution procedure. The contents of catalogue $\mathrm{C} 5$ and of these two associated procedure texts are summarized in Table 4 below.

[to the publisher: please insert Table 4: "Table 4: Groups in Catalogue C5 and Associated Procedure Texts"]

Both procedure texts, $\mathrm{P} 5 \mathrm{a}$ and $\mathrm{P} 5 \mathrm{c}$, are written on type $\mathrm{S}$ tablets. Neither of these two tablets contains a colophon. The statements, written in Sumerian, are almost identical to those in $\mathrm{C} 5$ and listed in the same order. The resolution, however, is written in Akkadian. ${ }^{32}$ Only the procedure texts corresponding to groups I and III of catalogue C5 are known. But it is highly probable that a procedure text corresponding to group II (denoted [P5b] in the Table 4 above) has existed.

The procedures associated with catalogues " $\mathrm{k}-\mathrm{I} \mathrm{a}_{2}$ " are thematically grouped and mathematically consistent, each group comprising the content of a tablet. It is notable that these tablets containing procedures texts do not include a colophon. These observations suggest that the catalogues were written after the procedure texts. Indeed, a catalogue such as C5 appears to be a compilation of statements extracted from several different procedure texts, the criterion chosen to group the statements into a single tablet being thematic.

\section{CLASSIFYING AND ARCHIVING}

Summarize the previous observations. The Yale catalogues are lists of statements written on type $S$ tablets, using the Sumerian language, and generally ending with the number of 
statements noted in a colophon. Each statement in a catalogue is introduced by a label, which indicates the theme of the tablet. This label is sometimes given again in the colophon (see $\mathrm{C} 5$ and $\mathrm{C7}$ ). The lists of statements are generated by various processes. In all the catalogues, the cyclic permutation of the parameters is used. In many cases, problems are nested (C4, C7 and C8). Some catalogues have a structure similar to that of a numerical table; this is notably the case for lists that provide the area or volume of various figures according to their linear dimensions (C3). Thus we find in these catalogues samples of the different processes that were used for generating mathematical lists during the Old Babylonian period. However, note that these processes operate on a scale limited to one group, but not always at the scale of the entire catalogue. Indeed, a single method of generating the list is found in C3 and C4. But in the other catalogues, the distinct groups made with distinct processes appear juxtaposed.

These observations stress the composite character of the majority of the catalogues, despite their thematic consistency. In particular, the existence of two procedure texts corresponding exactly to two groups in catalogue $\mathrm{C} 5$ suggests that the catalogues were probably compiled from existing procedure texts. The presence of colophon counting problems, sometimes with a label, suggests that the authors of the catalogues sought to inventory and classify the existing material. That intention, however, does not seem to apply to procedure texts, which do not generally contain a colophon. ${ }^{33}$ Therefore, two types of mathematical practices take shape. The first is a creative practice that produced the procedure texts. The second is a patrimonial practice of taking stock, classifying, and probably storing the accumulated knowledge. These classification efforts may have gone hand in hand with the constitution of the first libraries, which seem to have begun developing during the late eighteen century BCE (Glassner 2009: 10). ${ }^{34}$ Indeed the sources from the first millennium show that the colophon is a key tool in library management.

However, we must take care not to consider creation and classification as two different phases of a chronological development. Procedure texts and catalogues are broadly contemporary. If the catalogues were written after the procedure texts, such a succession would have involved the tablets individually, not the relevant mathematical material as a whole. For example, one scribe could have written some procedure texts, and subsequently compiled the material into catalogues for a possible use in a library. It is also noteworthy that procedure texts, by their progressive explanations of the methods of resolution, as well as catalogues, by their arrangements, appear strongly related to education in the scribal schools (for example C3). The practice of creating, teaching, and classifying should not be seen as successive phases, but as different facets of mathematical work that probably interacted with each other.

Another feature, the importance of which will emerge in the next section on series texts, must be added here. The statements written in catalogues always contain all the information needed by the resolution of the problems. Each problem statement could have been extracted from the catalogue and copied elsewhere in order to be solved, or used as a school exercise. I conclude that the catalogues seem to have been elaborated in order to classify and archive mathematical material used in advanced education. 


\section{SERIES TEXTS, SERIES TABLETS}

Like the catalogues, the series texts are lists of statements using mainly Sumerian ideograms with a colophon providing the number of sections ( $\mathrm{i} \mathrm{m}-\mathrm{s} \mathrm{u}$ ). Just as the catalogues, the series show thematic consistency (including field problems, brick problems, canal problems). Hence one might ask what is the difference between catalogues and series texts. ${ }^{35} \mathrm{~A}$ first difference is the serial organisation of the text. Thus an important distinction between text and tablet appears: a single series text is written on several series tablets. Another difference is the typology of the tablets: all the series tablets are of type $\mathrm{M}$. In the following, I argue that these differences are significant, and that beyond their apparent similarities, catalogues and series texts reflect radically different mathematical projects. To emphasise the particulars of the series, let us examine some examples.

\section{S1 (YBC 4708)}

The colophon of tablet S1 indicates that it is the first tablet in a series ( $\mathrm{d} u \mathrm{~b} 1-\mathrm{k}$ a $\mathrm{m}$ ). It is therefore particularly interesting to examine this tablet in order to understand how the lists are made. For this reason Neugebauer dwelled at length on "the first tablet", in which he analyzed the "organizing principle" (Neugebauer 1934-1936: 108). This type M (3/3) rectangular tablet is written in Sumerian without any Akkadian terms. According to its colophon the text is made up of " 1 sixty of sections", which corresponds to the actual number of sections ${ }^{36}$ (see figure 5). The problems relate to a pile of bricks, prism-shaped in the first statement, and pyramid-shaped in the following ones. The common introducer of all the statements is the expression "the bricks of a pile of bricks" (s ig 4 sig $_{4}$-a n š e), namely, the volume of the pile expressed by means of the number of standard bricks. This standard brick is model number 2 described in catalogue C3 (see Table 2).

[please insert Figure 5: "Fig. 5: Colophon of Tablet S1: end of the reverse (copy Neugebauer, Neugebauer 1935-1937, vol. I: Plate 57)]

The first column contains statements on the dimensions of a pile of bricks (five are preserved). The first statement gives the dimensions of the pile and requests its "brick" ( $\mathrm{s} \mathrm{i}_{4}$ ), that is, its volume expressed by means of number of standard bricks. In the next three sections (\#2-\#4), the statements give the volume as well as two dimensions and request the third dimension (successively the length, the width and the height). The following sections are related to quadratic problems. They give the volume of the pile, one dimension, as well as the sum (respectively difference) of the two others, and request the two unknown dimensions. The first statements are complete, that is, each section contains all the information. The thematic and mathematical content, the writing style, and the structure of the group are quite similar to those frequently found in the catalogues (for example $C 5$, group I). But a new feature appears in section \#11. The text of sections \#10 and $\# 11$ reads as follows:

\#10

The bricks of a pile of bricks (are) 3(iku) GAN 24 sar.

Its length is 5 ninda.

The width and the height I added: 2 ninda.

What are the width and the height? 
The width is $11 / 2$ ninda, its height is $1 / 2$ ninda.

\#11

The width over the height $1 \mathrm{n}$ inda goes beyond.

The statement in \#11 is incomplete: it lacks information; the question and the answer are also omitted. The missing information was in fact already given in section \#10, namely the volume and the length. By reintroducing the information given in \#10, the complete statement becomes:

\#11

$<$ The bricks of a pile of bricks (are) 3 (iku) $\mathrm{GAN}_{2} 24$ sar.

Its length is 5 ninda.>

The width over the height 1 ninda goes beyond.

$<$ What are the width and the height?

The width is $11 / 2 \mathrm{ninda}$, its height is $1 / 2 \mathrm{ninda.>}$

The process is developed in the following sections. Each statement is composed of four blocks of information, which in succession take a series of different values. This system of variations produces a tree-structured list with four levels. A defective distribution of information is grafted onto this tree-structured list. ${ }^{37}$ It is possible that on scale of the whole series, the tree-structured list would be developed on one or two more levels, which are not discernible on tablets when considered individually. The organization of the text in S1 is characteristic of the series texts, and distinguishes them from catalogues.

The process described above operates on the scale of one tablet, the first of a series. The process is continued, systematized and amplified in the following tablets. Let us see, how the list is developed in subsequent stages in tablets from another series.

\section{S13 (AO 9071)}

According to its colophon, $\mathrm{S} 13$, of type $\mathrm{M}(3 / 3)$, is the 7 th tablet in a series and contains 95 sections (see Figure 6).

[to the publisher: please insert Figure 6: "Fig. 6: Colophon of Tablet S13: end of the reverse (copy Proust 2009: 177)]

The text uses few grammatical elements, and the lexical repertoire is very limited (only about 20 different words are used in the whole text, which runs to more than 150 lines). The graphy is cursive and rather different from the archaic graphies found, for example, in school tablets and catalogues. The statements always refer to the same rectangle, the unknowns are the length and the width, and the solutions are always the same, namely 30 and 20 (length units are not always specified). The situation described in the problems, stripped of any realistic detail, is reduced to the simplest form: an abstract rectangle. In modern terms, the problems could be represented by systems of two equations with two unknowns and could be solved using linear or quadratic equations. The tree-structured list is expanded to the point that it reaches four or five levels and the system of ellipse is pushed as far as possible. 
This description applies fully to tablets S11 and S12, and partially to tablets S9 and S10, which are related to rectangles and squares. The four tablets belong to group $B$ as defined by Neugebauer (1935-1937, vol. I: xii, 386). This suggests that tablets S9, S10, S11, S12 and S13, which bear respectively the rank $3,4,5$, probably 6 , and 7 in their colophon, possibly belong to the same series. ${ }^{38}$ Tablet S14, very similar to S13, should probably also be included although its colophon was destroyed.

This brief description of S13 and other tablets in the same series allows to capture what is unique in the series texts. The first statements of the series refer to the usual repertoire of mathematics at the Old Babylonian period. As for the catalogues, we know some procedure texts, which provide detailed solutions to these or similar problems. But as we move through the list, we find statements of growing complexity and increasingly impressive embedded expressions. By the end of the list, the expressions contain up to five hierarchical levels of operations, which are represented in modern language by five levels of parentheses. For example, section \#59 of tablet $\mathrm{S} 13$ reads as follows:

I subtracted: 45 .

But after collecting the information in the relevant sections, namely section \#35, \#57 and $\# 50$, the reader discovers that this concise statement represents a quite monstrous problem. It could be represented in modern language through the following system of equations:

$\left\{\begin{array}{l}(3 x+2 y) \frac{1}{13}+x=40 \\ -\left\{\left\{\left\{[(x+25)+(y+1.30-x)+(x+y+35)] \frac{1}{11}+4 x\right\} \frac{1}{7}+y\right) \times 2 \times \frac{1}{16}-(x+2 y)+x+y+(3 x-2 y)\right\} \frac{1}{7}+(x+y)=45\end{array}\right.$

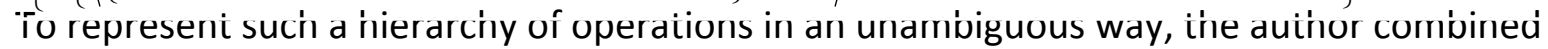
various methods. The syntactical resources for the operations are much more elaborate in series texts than they are in catalogues. The tree-structured organisation of the lists and the defective distribution of the information allow the prioritization of the expressions almost without limit. The unlimited nature of the process probably did not escape the scribes. We will now see how the scribes tried to expand the development of lists on a scale even greater than that of the series.

S5 (YBC 4713), S6 (YBC 4712), AND S4 (YBC 4668)

Tablet $\mathrm{S} 5$ is, according to the colophon, the tenth tablet in a series and contains 37 sections. Like most of the series tablets it is type $M(3 / 3)$ (see figure 7).

[to the publisher: please insert Figure 7: "Fig. 7: Colophon of Tablet S5: end of the reverse (copy Neugebauer, Neugebauer 1935-1937, vol. I: Plate 59)]

The statements concern a rectangle, the unknowns are length and width, and the solutions are always the same: the length is $\mathbf{3 0}$ ninda and the width is 20 ninda. The data given is the area of the rectangle, linear combinations of length and width, whose coefficients are unknown, and linear combinations of these coefficients (actually four unknowns: the length, the width and the two coefficients). The problems could thus be represented in modern 
language by systems of four equations with four unknowns and could be solved using quadratic equations. The syntax and terminology show many peculiarities, and many difficulties that have been resolved brilliantly by Neugebauer (1935-1937, vol. I, ch. 7). In terms of its structure, the list of statements is comparable to the one found in tablet S1 described above.

Tablet $\mathrm{S} 6$ is, according to the colophon, the 13th tablet in a series and contains 48 sections. It is also type $\mathrm{M}(3 / 3)$; see figure 8.

[to the publisher: please insert Figure 8: "Fig. 8: Colophon of Tablet S6: end of the reverse (copy Neugebauer, Neugebauer 1935-1937, vol. I, Plate 59)]

The statements in S6 concern the same rectangle with the same solutions as in S5. In the first group of statements, the data provides the area, the width after undergoing a

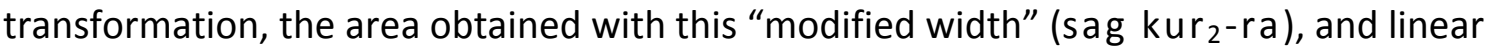
combinations of length and modified width. The problems could be represented in modern language by systems of three equations with three unknowns, which require quadratic equations. In a second group of problems, the data provides the area and linear combinations of ratio length/width (igi-te-en sag uš-še ${ }_{3}$ ) and ratio width/length (igi-te-en $u s s a g$-š $e_{3}$ ). The resolution of the problems requires quadratic equations in $x^{3}$. This second group is tree-structured with three levels and a system of ellipse similar to S1.

Tablet S4 is, according to its colophon, the third of a series and contains 286 sections. The text is densely noted and the type of the tablet is $M(5 / 5)$. The list of statements it contains is much longer than the ones we have encountered so far. The remarkable fact, emphasized by Neugebauer (1935-1937, vol. I: 420), is that this list includes those of S5 and S6, which are reproduced almost word-by-word and in the same order. Table 5 below shows the relationship between S4, S5 and S6:

[to the publisher: please insert Table 5: "Table 5: Series and Super-series (According to Neugebauer 1935-1937, vol. I: 421)]

So we have before us two kinds of lists, series and "series of series" (that is super-series or Oberserie in ibid.: 385), the latter containing the former. The series are composed of $M(3 / 3)$ tablets with about 40 to 80 problems each. The super-series is composed of $M(5 / 5)$ tablets containing approximately 200 to 300 problems each.

\section{CREATING ENDLESS NEW MATERIAL}

As we did with the catalogues, we can now provide a more accurate picture of the series texts. We have just seen that series texts are lists of statements written on several type $M$ tablets, each tablet bearing a colophon with the number of the statements and the rank of the tablet. The language is Sumerian, or at least has the appearance of Sumerian. We can now add some features, which do not appear in the catalogues. The series texts are tree structured, with a defective distribution of the information. The system of giving titles (a label introducing the statements and sometimes given again in the colophon) is not as well developed as in the catalogues. 
But the major difference between catalogues and series texts lies in the mathematical content of the problems. Indeed, one could wonder if the problems listed in the series texts were produced specifically in order to be solved. The first problems in the series tablets generally belong to the common Old Babylonian mathematical repertoire and were well known by the scribes of the time. However, the lists of statements are constructed so that the repertoire of statements is considerably extended along the way. It is interesting in this regard to compare the number of sections in the catalogues and in the series. The average number of sections is 28 in the catalogues, 55 in the series tablets, and 244 in the superseries tablets. If one estimates that a series was composed of about a dozen tablets, then a complete series text should contain over 500 statements. Since the colophon of tablet S19 shows that a super-series can contain up to 10 tablets, a complete super-series should contain over 2,000 statements. The orders of magnitude are very different: tens statements in catalogues, hundreds in series and thousands in super-series. The series do not reflect a simple practical classification of existing material, but rather reveal a powerful mechanism that created thousands of new problem statements. Innovative work does not involve methods for solving problems, which in any case are absent from these texts, but rather focuses on the statements themselves, and more specifically, on the mechanism of actually making lists of statements.

Moreover, the nature of the textual operations is different in catalogues and in series. I have shown above that the catalogues seem to result from a compilation of statements collected from procedure texts. The text obtained by this operation (catalogues) is different in nature from the original texts (procedure texts). The "super-series" results from the concatenation of several smaller series. The nature of the derived text is identical to the original texts, but developed into a larger scale. We can compare this process to the one used in neo-Sumerian administration, where accounts relating to large-scale works were elaborated from collections of partial local accounts. In the Hellenistic period, the records of astronomical observations resulted in the same process from the collection of partial observations made locally in the various observatories scattered throughout Mesopotamia. Series may be preparatory works for super-series, in the same way as sketches are preparatory for artwork.

\section{THE DIVERSITY OF MATHEMATICAL PRACTICES}

The catalogues, which all seem to come from the same city probably located in southern Mesopotamia, are often composite and most likely a result from the practice of compilation. These textual operations left traces in the colophon, which show some important elements of the collection process: counting the sections and sometimes naming the subject of the compilation. The authors of the compilations may have pursued several non-exclusive goals : the organisation of a curriculum, the development of libraries, and the preservation of intellectual heritage. Since information on the archaeological context of these tablets is lost, it is difficult to decide more precisely between these alternatives. Very homogeneous, progressive, and coherent catalogues such as C2 and C3 may be textbooks composed for teaching purposes. Composite catalogues such as $\mathrm{C} 5, \mathrm{C} 7$ and $\mathrm{C} 8$ seem to be more related to the management of libraries and perhaps to the establishment, preservation, and transmission of mathematical knowledge. 
As noted by Høyrup (2002: 351), it is likely that the series texts were written when the Old Babylonian mathematical traditions had already been fully developed. Evidence suggests that series texts came from central Mesopotamia. They could have been the work of communities established in northern Mesopotamia after the destruction of southern cities in the mid-eighteenth century. Importantly, the series texts appear to result from a new intellectual project. In writing the series texts, the scribes produced new mathematical material that represented a considerable extension of the repertoire compiled in the catalogues. The scribes' interest no longer focused on procedures, but on statements. Writing techniques improved. The syntax of operations became more elaborate. But above all, being based on tree structures, the new techniques multiplied the potential of the previous syntax. The dynamic of these new techniques led to the enumeration of hundreds or thousands of problem statements all concentrated in the limited space of small clay tablets.

Catalogues and related procedure texts as well as series texts exemplify various ways of composing mathematical texts. This article suggests that these operations reflect different intellectual practices: a creative practice focused on the resolution of problems, a patrimonial practice of inventorying, classifying, and probably preserving the accumulated knowledge, and a heuristic approach focused on the statements of the problems.

\section{Appendix 1: Catalogues, Series and Colophons}

This appendix contains an inventory of mathematical catalogues and series texts. I have indexed the Yale catalogues from C1 to C8 and series texts from S1 to S20 for the needs of works in progress (a book on "L'art des listes" and a digital publication of catalogues and series texts). For consistency throughout my different publications, I use this indexation here.

\section{Catalogues}

The catalogues known to date are given in Table A of this Appendix. The majority of these catalogues was purchased by the Yale Babylonian Collection, probably all from the same dealer, between 1911 and 1919 (Neugebauer 1935-1937, vol. I: 387). It is therefore possible that these tablets came from the same city. This city may be Larsa, which was the subject of extensive illegal excavation during the years 1910-1920, supplying a major part of the antiquities market, but this provenance is far from certain.

The encoding rules used in the tables below are the following.

[...] Unreadable or broken part. One cannot know if a colophon existed.

$\varnothing \quad$ No colophon.

The first column contains my own indexation of the tablets. 


\begin{tabular}{|c|c|c|c|c|c|}
\hline & $\begin{array}{l}\text { Museum } \\
\text { number }\end{array}$ & $\begin{array}{l}\text { Typ } \\
\text { e }\end{array}$ & Prov. & Content & Colophon \\
\hline $\begin{array}{l}C \\
1\end{array}$ & YBC 4612 & $S$ & unknown & $\begin{array}{l}15 \text { sections on fields ( } a- \\
\mathrm{š}_{3} \text { ) }\end{array}$ & $\varnothing$ \\
\hline $\begin{array}{l}C \\
2\end{array}$ & YBC 6492 & $S$ & unknown & $\begin{array}{l}24 \text { sections on fields ( } \mathrm{a}- \\
\mathrm{s}_{3} \text { ) }\end{array}$ & $\varnothing$ (unfinished tablet?) \\
\hline $\begin{array}{l}C \\
3\end{array}$ & YBC 4607 & $S$ & unknown & 10 sections on bricks ( $\mathrm{s} \mathrm{i} \mathrm{g}_{4}$ ) & $\begin{array}{l}10 \text { sections (10 i m - } \\
\text { š u-m e š) }\end{array}$ \\
\hline $\begin{array}{l}C \\
4\end{array}$ & YBC 4652 & $S$ & unknown & 22 sections on stones $\left(\mathrm{n} \mathrm{a}_{4}\right)$ & $\begin{array}{l}22 \text { sections (22 [i m - } \\
\text { š u ]) }\end{array}$ \\
\hline $\begin{array}{l}\text { C } \\
5\end{array}$ & YBC 4657 & $S$ & unknown & $\begin{array}{l}31 \text { sections on trenches } \\
\left(\mathrm{ki}-\mathrm{a}_{2}\right)\end{array}$ & $\begin{array}{l}31 \text { sections on } \\
\text { trenches ( } 31 \mathrm{i} \mathrm{m}-\mathrm{s} \mathrm{u} \\
\mathrm{ki}-\left(\mathrm{a}_{2}\right)\end{array}$ \\
\hline $\begin{array}{l}C \\
6\end{array}$ & YBC 5037 & $S$ & unknown & $\begin{array}{l}44 \text { sections on trenches } \\
\left(\mathrm{ki}-\mathrm{I}_{2}\right)\end{array}$ & $\begin{array}{l}44 \text { sections ( } 44 \text { i m - } \\
\text { š u) }\end{array}$ \\
\hline $\begin{array}{l}\text { C } \\
7\end{array}$ & YBC 4666 & $S$ & unknown & $\begin{array}{l}26 \text { sections on canals }\left(\mathrm{pa}_{5^{-}}\right. \\
\text {sig) }\end{array}$ & $\begin{array}{l}26 \text { sections (26 i m - šu } \\
\left.p_{5}-\mathrm{sig}\right)\end{array}$ \\
\hline \multirow[t]{6}{*}{$\begin{array}{l}C \\
8\end{array}$} & YBC 7164 & $S$ & unknown & $\begin{array}{l}19 \text { sections on canals }\left(\mathrm{pa}_{5^{-}}\right. \\
\text {sig) }\end{array}$ & $\varnothing$ \\
\hline & BM 80209 & $S$ & $\begin{array}{l}\text { unknown } \\
\text { (north?) }\end{array}$ & $\begin{array}{l}18 \text { sections on canals }\left(\mathrm{pa}_{5^{-}}\right. \\
\text {sig) }\end{array}$ & $\varnothing$ \\
\hline & IM 52672 & $?^{39}$ & $\begin{array}{l}\text { unknown } \\
\text { (north?) }\end{array}$ & $2+$ sections on fields & Destroyed? \\
\hline & $\begin{array}{l}\text { IM } 52916+ \\
\text { IM } 52685+ \\
\text { IM } 52304\end{array}$ & $S$ & $\begin{array}{l}\text { tell } \\
\text { Harmal } \\
\text { (north) } \\
\end{array}$ & $\begin{array}{l}70+\text { sections on fields and } \\
\text { coefficients table }\end{array}$ & {$[\ldots]$} \\
\hline & TMS 5 & $\begin{array}{l}M(3 \\
/ 3)\end{array}$ & Susa & 262 sections on squares & $\begin{array}{l}262 \text { lines }(4.22 \mathrm{mu}-\mathrm{bi} \\
\mathrm{n} \text { ig in-m e š })+ \text { date }+ \\
\text { NP }\end{array}$ \\
\hline & TMS 6 & $\begin{array}{l}M(2 \\
+/ 2+ \\
)\end{array}$ & Susa & $60+$ sections on squares & {$[\ldots]$} \\
\hline
\end{tabular}

Table A: Old Babylonian Catalogues

\begin{tabular}{|l|l|l|l|l|}
\hline $\begin{array}{l}\text { Museum } \\
\text { number }\end{array}$ & Type & Prov. & Content & Colophon \\
\hline MS 3052 & S & unknown & $\begin{array}{l}\text { 8 procedure texts } \\
\text { (construction, diagonal, } \\
\text { trench, square) }\end{array}$ & $\begin{array}{l}\text { 8 sections (8 i m - š u- } \\
\text { m e š ) + } \\
\text { summary }\end{array}$ \\
\hline MS 5112 & M(2/2) & unknown & 23 procedure texts on fields & $\begin{array}{l}\text { Total 23 sections (šu- } \\
\text { nigin 23 im - š u- } \\
\text { m e š ) }\end{array}$ \\
\hline
\end{tabular}

Table B: Old Babylonian Procedure Texts Providing the Number of "im-šu”

Series Texts

The inventory of all the series texts known to date can be found in Table $\mathrm{C}$ of this Appendix. I followed the order of the tablets given in Neugebauer 1935-1937, but slightly modified: I 
have added four tablets and deleted one. Two of the former I had discovered in the Louvre and published recently (Proust 2009). I tagged them S13 and S14 because most likely they belong to the same series as S12. I also added the two tablets now kept at the Oriental Institute of Chicago (S19 and S20) that Neugebauer and Sachs subsequently published in 1945. Two other series texts from Susa (published in Scheil 1938 under the numbers 1 and 2) are not included here. ${ }^{40}$

Neugebauer tried to find criteria that would permit him to identify the tablets belonging to the same series. The result, however, did not satisfy him. ${ }^{41}$ Thus he decided to divide the tablets into three groups ( $A, B$ and $C$ ), trying to classify only the tablets belonging to the same series in the same group (Neugebauer 1935-1937, vol. I: 386). These groups are noted in the last column of Table C (entitled “Group MKT").

\begin{tabular}{|c|c|c|c|c|c|c|}
\hline & $\begin{array}{l}\text { Museum } \\
\text { number }\end{array}$ & Type & Content & Colophon & Rank & $\begin{array}{l}\text { Group } \\
\text { MKT }\end{array}$ \\
\hline S1 & YBC 4708 & $M(3 / 3)$ & $\begin{array}{l}60 \text { sections on } \\
\text { bricks }\end{array}$ & $\begin{array}{l}1 \text { sixty sections / Tablet No. } \\
1 \text { (1 šu-ši im-š } / \mathrm{d} u \text { b } \\
1-\mathrm{k} a \mathrm{~m}-\mathrm{m} a)\end{array}$ & 1 & A \\
\hline S2 & YBC 4710 & $\mathrm{M}(3 / 3)$ & $\begin{array}{l}35 \text { sections on } \\
\text { fields }\end{array}$ & $\begin{array}{l}\text { [35] sections / Tablet No. } 4 \\
\text { ([35 im ]- šu / [dub] 4- } \\
\text { kam-ma) }\end{array}$ & 4 & $A$ \\
\hline S3 & YBC 4709 & $\mathrm{M}(3 / 3)$ & $\begin{array}{l}55 \text { sections on } \\
\text { fields }\end{array}$ & $\begin{array}{l}55 \text { sections / Tablet No. } 5 \\
\text { (55 im-šu d u b } 5-k a m- \\
\text { ma ) }\end{array}$ & 5 & $A$ \\
\hline S4 & YBC 4668 & $M(5 / 5)$ & $\begin{array}{l}286 \text { sections } \\
\text { on fields }\end{array}$ & $\begin{array}{l}286 \text { sections / Tablet No. } 3 \\
\text { (4(geš } 2 \text { ) } 46 \text { i m - š u / d u b 3- } \\
\text { ka m - ma) }\end{array}$ & 3 & $A$ \\
\hline S5 & YBC 4713 & $M(3 / 3)$ & $\begin{array}{l}37 \text { sections on } \\
\text { fields }\end{array}$ & $\begin{array}{l}37 \text { sections / Tablet No. } 10 \\
\text { ( } 37 \mathrm{im}-\mathrm{s} \mathrm{u} / \mathrm{d} \text { u b } 10- \\
\mathrm{kam}-\mathrm{ma} \text { ) }\end{array}$ & 10 & $A$ \\
\hline S6 & YBC 4712 & $M(3 / 3)$ & $\begin{array}{l}48 \text { sections on } \\
\text { fields }\end{array}$ & $\begin{array}{l}48 \text { sections / Tablet No. } 13 \\
\text { (48 im-šu / d u b 13- } \\
\text { ka m-ma) }\end{array}$ & 13 & $A$ \\
\hline S7 & VAT 7537 & $\mathrm{M}(3 / 3)$ & $\begin{array}{l}40+\text { sections } \\
\text { on fields }\end{array}$ & {$[\ldots]$} & $?$ & $A$ \\
\hline S8 & YBC 4715 & $M(3 / 3)$ & $\begin{array}{l}\text { ca. } 60 \text { sections } \\
\text { on fields }\end{array}$ & $\begin{array}{l}\text { x sections / tablet No. x ([...] } \\
\text { / d u b }[\ldots])\end{array}$ & $x$ & $A$ \\
\hline S9 & YBC 4697 & $\mathrm{M}(2 / 2)$ & $\begin{array}{l}25 \text { sections on } \\
\text { fields }\end{array}$ & $\begin{array}{l}25 \text { sections / Tablet No. } 3 \\
\text { (im-šu / d u b 3-ka m- } \\
\text { ma) }\end{array}$ & 3 & $B$ \\
\hline S10 & YBC 4714 & $M(5 / 5)$ & $\begin{array}{l}39 \text { sections on } \\
\text { fields }\end{array}$ & $\begin{array}{l}43 \text { sections / tablet No. } 4 \\
\text { (43 i m-š u / d ub 4- } \\
\text { ka m-ma) }\end{array}$ & 4 & $B$ \\
\hline S11 & YBC 4695 & $\mathrm{M}(3 / 3)$ & $\begin{array}{l}97 \text { sections on } \\
\text { fields }\end{array}$ & $\begin{array}{l}97 \text { sections / tablet No. } 5 \\
\left(1 \text { geš }_{2}\right) 37 \text { i m-šu / } \\
\text { dub } 5-k a m-m a)\end{array}$ & 5 & $B$ \\
\hline S12 & YBC 4711 & $\mathrm{M}(3 / 3)$ & 131 sections & 131 sections / tablet No. 6 & 6 & $\mathrm{~B}$ \\
\hline
\end{tabular}




\begin{tabular}{|c|c|c|c|c|c|c|}
\hline & & & on fields & $\begin{array}{l}\left(2\left(\text { geš }_{2}\right) 11 \text { im-šu d ub 6- }\right. \\
\text { kam-ma) }\end{array}$ & & \\
\hline S13 & AO 9071 & $M(3 / 3)$ & $\begin{array}{l}95 \text { sections on } \\
\text { fields }\end{array}$ & $\begin{array}{l}95 \text { sections / tablet No. } 7 \\
\left(1 \text { geš }_{2}\right) 35 \text { i m-šu / d u b } \\
7-\mathrm{ka} \mathrm{m-ma)}\end{array}$ & 7 & (B) \\
\hline S14 & AO 9072 & $M(4 / 5)$ & $\begin{array}{l}\text { ca. } 180 \\
\text { sections on } \\
\text { fields }\end{array}$ & {$[\ldots]$} & $?$ & (B) \\
\hline S15 & YBC 4696 & $\mathrm{M}(3 / 3)$ & $\begin{array}{l}52 \text { sections on } \\
\text { triangles }\end{array}$ & 52 sections (52 i m - š u) & $\varnothing$ & $B$ \\
\hline S16 & YBC 4673 & $\mathrm{M}(3 / 3)$ & $\begin{array}{l}22 \text { sections on } \\
\text { bricks }\left(\text { s } i g_{4}\right)\end{array}$ & $\begin{array}{l}23 \text { sections / Tablet No. } 2 \\
(23 \text { i } \mathrm{m}-\mathrm{s} \text { u d u b 2-ka m- } \\
\mathrm{ma} \text { ) }\end{array}$ & 2 & C \\
\hline S17 & VAT 7528 & $M(3 / 3)$ & $\begin{array}{l}19 \text { sections on } \\
\text { canals }\end{array}$ & $\begin{array}{l}14 \text { sections / Tablet No. } 3 \\
\text { (14 im-šu dub 3-ka m- } \\
\text { ma) }\end{array}$ & 3 & C \\
\hline S18 & YBC 4698 & $M(2 / 2)$ & $\begin{array}{l}17 \text { sections on } \\
\text { buying and } \\
\text { selling }\end{array}$ & $\begin{array}{l}\text { x sections / Tablet No. ([...] } \\
\text { d u b 3-k a m - m a) }\end{array}$ & 3 & C \\
\hline S19 & A 24194 & $M(5 / 5)$ & $\begin{array}{l}247 \text { sections } \\
\text { on fields }\end{array}$ & $\begin{array}{l}240 \text { / sections / Tablet No. } \\
10 \text { (4 šu-ši / i m-š u / } \\
\text { d u b 10-k a m-ma) }\end{array}$ & 10 & \\
\hline S20 & A 24195 & $M(5 / 5)$ & $\begin{array}{l}200 \text { sections } \\
\text { on fields }\end{array}$ & $\varnothing$ (unfinished tablet?) & $\varnothing$ & \\
\hline
\end{tabular}

Table C: Series Texts

\section{Appendix 2: Metrological Systems}

The following diagrams represent the metrological systems taught in scribal schools, and widely used during the Old Babylonian period in Mesopotamia.

Capacities units ( 1 sila $_{3} \approx 1$ litre)

gur $\leftarrow \times 5-$ bariga $\leftarrow \times 6-$ ban $_{2} \leftarrow \times 10-$ sila $_{3} \leftarrow \times 60-\operatorname{gin}_{2}$

Weight units $\left(1 \mathrm{gu}_{2} \approx 30 \mathrm{~kg}\right)$

$\mathrm{gu}_{2} \leftarrow \times 60-$ ma-na $\leftarrow \times 60-\mathrm{gin}_{2} \leftarrow \times 180-$ še

Area units $\left(1 \mathrm{sar} \approx 36 \mathrm{~m}^{2}\right)$

GAN $_{2} \leftarrow \times 100-$ sar $\leftarrow \times 60-\operatorname{gin}_{2} \leftarrow \times 180-$ še

Length units $(1$ ninda $\approx 6 \mathrm{~m})$

danna $\leftarrow \times 30-$ UŠ $\leftarrow \times 60-$ ninda $\leftarrow \times 12-$ kušs $\leftarrow \times 30-$ šu-si

\section{Acknowledgements}

UMI Transitions (CNRS \& New York University); SPHERE (CNRS \& University Paris Diderot). I wrote this article at the Institute for Advanced Study, Princeton, in the framework of a 
membership funded by the Otto Neugebauer Fund (fall 2009). Its content is the result of work on "paratexts" conducted in the seminar Histoire des Sciences, Histoire des Textes of the REHSEIS Unit (CNRS/University Paris Diderot) in 2008-2009. I improved my first draft thanks to the discussions that took place in the Ancient Studies Seminar of IAS, headed by Heinrich von Staden. I am deeply indebted to my colleagues, both in Paris and Princeton, for their suggestions, ideas and criticisms, which helped me to complete this study. My warmest thanks also go to Richard Kennedy, as well as the reviewers and the editors of the journal for their careful reading, and their scientific and linguistic suggestions which improved substantially the first drafts of this paper.

\section{Endnotes}

${ }^{1}$ For information on the colophons in the first millennium BCE, see also Leichty 1964 and Hunger 1968.

${ }^{2}$ For a description of colophons in mathematical texts published before 1945 , see Robson 1997: 58, 67-70.

${ }^{3}$ Appendix 1 provides more information on catalogues and series texts: sources, provenance, content, publication.

${ }^{4}$ An almost complete inventory of the currently known mathematical corpus is available at the Cuneiform Digital Library Initiative database (http://cdli.ucla.edu/) [April 15, 2012], 1835 mathematical tablets and fragments from all periods are inventoried by CDLI. More than 200 yet unpublished tablets should be added to this figure (material recently discovered in Mari as well as unpublished tablets kept in various museums and private collections). For a survey of the historiography of cuneiform mathematics see Hoyrup 1996.

${ }^{5}$ See Veldhuis 1997 for a detailed description of the typology of school tablets and for related bibliography.

${ }^{6}$ Figures 1-4 offer samples of type $S$ tablets, and Figure 5-8 samples of type $M$ tablets. In type $\mathrm{M}$ tablets, the columns run from left to right on the obverse of the tablet, but from right to left on the reverse. Thus, the end of the text noted in a tablet is generally located in the bottom of the left column of the reverse.

${ }^{7}$ Tinney 1999, Robson 2001 and Delnero 2010 show that type S and M tablets may have been used in combination in southern scribal schools to study specific groups of mathematical or literary texts.

${ }^{8}$ The relationship between the typology of tablets, the category of texts and the elementary mathematical curriculum in Nippur is analyzed in depth in Proust 2007.

${ }^{9}$ See also Robson 2008: 87. Denominations and definitions used by Robson are not exactly the same as in her two books. In Robson 1999 , "catalogues" are limited to a few texts kept in the British Museum and the Louvre; in Robson 2008, "catalogues" seem to include Yale material and Plimpton 322. In both books, series texts do not exist as a category (or "genre"). In Robson 1997 (p. 67-70) catalogues and series texts are mingled together in the common category of "series of problems".

${ }^{10}$ A catchline is an additional item noted at the end of a section of text, indicating the first item of the next section.

${ }^{11}$ In school and scholarly texts, the doxology is usually a formula of praise to Nisaba the goddess of scribes. The doxology generally appears in the colophon. But in tablet AO 8862, the name of Nisaba is mentioned in the first line of the list of problems. 
${ }^{12}$ For administrative archives, see for example Veenhof 1986; for school tablets see Beaulieu 1992 and Veldhuis 1997; for Sumerian literary corpuses, see examples analysed in Tinney 1996; for divination, see the case of Extispicium in Goetze 1947, Jeyes 1989, Glassner 2009. ${ }^{13}$ See Neugebauer 1935-1937, vol. I: chapter I, Robson 1997, 2008: 307-320, Proust 2007.

${ }^{14}$ To my knowledge, tablets that are not strictly school tablets bearing colophons including these elements are the following: AO 8862, AO 8865, BM 85210, IM 73355, MS 2723, BM 96957 + VAT 6598, YBC 5022.

${ }^{15}$ Labels in other categories of texts are also attested. Interesting examples can be found in tables of length and height noted in some tablets from Ur in Friberg (2000: 155-156), in a reciprocal table Scheil (1915: 195-198), Neugebauer (1935-1937, vol. I: 10 number 4, 26), in a special reciprocal table (MS 1844, Friberg 2007: 182-183), and in lists of problems (MS 3052, Friberg 2007: 278.; MS 3049, ibid: 295- 307).

${ }^{16}$ Two languages were used in mathematical cuneiform texts: Sumerian and Akkadian. Sumerian was spoken in southern Mesopotamia in the third millennium BCE, and probably disappeared as a first language before the Old Babylonian period. However, Sumerian was used as a scholarly language until the abandon of cuneiform writing around the beginning of the Common Era. Akkadian, a Semitic language, was spoken in Mesopotamia during the late third, second and early first millennium BCE. In cuneiform texts, the graphic system is ideographic for Sumerian, and syllabic for Akkadian. Even when writing in Akkadian, the scribes often used many Sumerian ideograms. In the transcriptions, Sumerian words are noted with spaced font (e.g.: i m - š u ), and Akkadian words with italics (e.g. kibsu).

${ }^{17}$ One of the meanings of the Sumerian term " $m u$ " (Akkadian equivalent šumu) is: "line, item, entry" (Black et al. 2000: 294). The term "mu" with this meaning appears in colophons in some Old Babylonian divination, literary or lexical texts as well as in headings of lists (Black/Georges/Postgate 2000: 296; Glassner 2009: 6). The expression "mu-bi-im" that appears in the heading of the last columns of the mathematical table Plimpton 322, is usually translated by "his name is" in publications related to this tablet. But it is clear that here, the term mu means "line"; note that this correction is suggested in Friberg (2007: 435) and assumed in Britton et al. (2011: 526).

${ }^{18}$ These tablets are the following: AO 8865, NBC 2513, MS 3049, TMS 5, Plimpton 322.

${ }^{19}$ See Thureau-Dangin (1938: 148, note 1) and Proust (2009: 194). The term im-šu is translated as "case" by Thureau-Dangin (passim), and "section, paragraph (separated off by lines)" by Neugebauer/Sachs 1945: 165.

${ }^{20}$ In the inventory provided in Appendix 1, catalogues are tagged " $\mathrm{C} 1$ " to " $\mathrm{C} 8$ ", and series texts are tagged "S1" to "S22". For more explanation, see this Appendix.

${ }^{21}$ YBC = Yale Babylonian Collection (Yale University); AO = Antiquités Orientales (Musée du Louvre, Paris); VAT = Vorderasiatische Abteilung Tontafeln (Vorderasiatisches Museum, Berlin); OI = Oriental Institute (Chicago).

${ }^{22}$ Some explanation on the orientation of the tablets may be useful. Cuneiform writing is read from left to right. When the user finishes reading the obverse, he turns the tablet around a horizontal axis along the lower edge. The descriptors of orientation I use refer to the obverse of the tablet. For example, the "upper edge" means the "upper edge of the obverse" (which is the lower edge of the reverse). See figure 1.

${ }^{23}$ This term is not attested outside of mathematical texts (Black/Georges/Postgate 2000, 18: 33) and does not appear to have a Sumerian equivalent. 
${ }^{24}$ The translations are those of Neugebauer/Sachs 1945. See the synthetic description of the metrological systems in Appendix 2.

25 "oil, the equivalent of its volume" is a literal translation of the expression " $i_{3}$ šam 2 sahar-bi", which means the volume of the liquid equivalent, namely the capacity.

${ }^{26}$ This text provides one of the major sources used by Powell 1982 in his study of the volume units. More on the use of the different volume units in mathematical texts can be found in Proust 2007: chapter 6, §6.6 and chapter 7.

${ }^{27}$ Some precisions on modern mathematical terminology may be useful here. By "linear" problem, I mean a problem of first degree, namely, which is solved by multiplications or divisions, as well as, in some cases, additions and subtractions. A quadratic problem is a problem of second degree, whose solution requires the extraction of a square root. The terms "linear", "quadratic", "change of variables", "coefficient" and others may appear anachronistic. However, two points must be underlined. First, here, I do not attribute the notion of "change of variables " to the ancient author, but I use it in a modern descriptive system. Second, almost all the modern mathematical terms are anachronistic. For example, the notions of integer, fraction, number, and division hardly fit with ancient conceptions. In the floating place value system used in mathematical texts, there is no difference between integer and fraction, but there is an essential difference between regular and non regular sexagesimal numbers (see Proust 2008a and included bibliography). The fractions used in statements of problems should be understood as parts of something. The "division" does not exist as an operation in the context of Old Babylonian mathematical texts, as division are performed through the multiplication by a reciprocal. The important point, in my view, is to be clear on the distinction between what is said exactly in our sources (for this reason, my translations are close to the original text), and what is the commentary of the modern historian.

${ }^{28}$ Melville 2002 has shown convincingly that the method of false position was probably used in solving problems similar to this basic pattern.

${ }^{29}$ My emphasis.

${ }^{30}$ This interpretation of the syntax of the operations is confirmed by the analysis of series texts (Neugebauer 1935-1937, vol. I: chapter. 7, Proust forthcoming).

${ }^{31}$ Perhaps the scribe who wrote $\mathrm{C7}$ wanted to distinguish two homonymous signs: the grapheme that represents the length unit (UŠ, equal to $60 \mathrm{ninda}$ ) and the grapheme that represents the length (uš).

32 This kind of split in the language, which contrasts statements and procedures, is not frequent in mathematical cuneiform texts.

${ }^{33}$ The case for procedure tablets kibsu, probably from later period and Northern origin, shows another tradition.

${ }^{34}$ One wonders if the place of colophons on tablets could be related to storage practices. There does not seem to be such a relationship. Indeed, of the five colophons of catalogues, two are placed on the left edge, and the other at the end of the text, on the upper edge (one case) or on the reverse (two cases).

${ }^{35}$ In his first publications Neugebauer (1934-1936; 1935-1937) had recognized a very strong identity to the series texts. The subsequent discovery of the Yale material however led him to revise his assessment: The conclusion reached by Neugebauer/Sachs (1945: 37) when they published the Yale catalogues in 1945 was that, in fact, series texts do not exist as a category. To a certain degree, the present analysis will revive Neugebauer's first impression. 
${ }^{36} 58$ sections are visible, at least partially. The end of the first column of the obverse, which is damaged, should contain two sections (Neugebauer 1935-1937, vol. I: 390).

${ }^{37}$ Tree-structured lists are extensively analysed in (Proust 2009, forthcoming).

${ }^{38}$ For more information about S13 and S14, see (Proust 2009).

${ }^{39}$ The publisher (Bruins 1954) did not provide a copy nor a description of the tablet.

${ }^{40}$ More explanations on the way in which the twenty series texts are selected will be provided in my book in progress on L'art des listes.

41 "Weder Tafelform noch Schreibweise, noch Terminologie liefern übereinstimmende Einteilungsprinzipe." (Neugebauer 1935-1937, vol. 1385).

\section{References}

Beaulieu, Paul-Alain, 1992. Antiquarian Theology in Seleucid Uruk. Acta Sumerologica, 14, 47-76.

Black, Jeremy/Georges, Andrew R./Postgate, Nicholas, 2000. A Concise Dictionary of Akkadian. Wiesbaden: Harrassowitz.

Britton, John P./Proust, Christine/Shnider, Steve, 2011. Plimpton 322: a Review and a Different Perspective. Archive for History of Exact Sciences 65,519-566.

Bruins, Evert, 1954. Some Mathematical Texts. Sumer, 10, 55-61.

Clancier, Philippe, 2009. Les bibliothèques en Babylonie dans la deuxième moitié du ler millénaire, [= Alter Orient und Altes Testament, 363]. Münster: Ugarit Verlag.

Delnero, Paul, 2010. Sumerian Extract Tablets and Scribal Education. Journal of Cuneiform Studies, 62, 53-69.

Englund, Robert/Renn, J. Cuneiform Digital Library Initiative (CDLI). University of California, Los Angeles/Max Planck Institute for the History of Science, Berlin [URL: http://cdli.ucla.edu/ (28/01/2012)].

Friberg, Jöran, 2000. Mathematics at Ur in the Old Babylonian Period. Revue d'Assyriologie, 94, 98-188.

Friberg, Jöran, 2007. A Remarkable Collection of Babylonian Mathematical Texts. New York: Springer.

Glassner, Jean-Jacques, 2009. Ecrire des livres à l'époque paléo-babylonienne: le traité d'extispicine. Zeitschrift für Assyriologie und Vorderasiatische Archäologie, 99, 1-81.

Goetze, Albrecht, 1945. The Akkadian Dialects of the Old-Babylonian Mathematical Texts. In: Otto Neugebauer and A. Sachs, eds, Mathematical Cuneiform Texts. New Haven: American Oriental Society, 146-151.

Goetze, Albrecht, 1947. Old Babylonian Omen Texts. New Haven: Yale University.

Høyrup, Jens, 1996. Changing Trends in the Historiography of Mesopotamian Mathematics. An Insider's View. History of science, 34, 1-32.

Høyrup, Jens, 2002. Lengths, Widths, Surfaces. A Portrait of Old Babylonian Algebra and its Kin. Berlin/London: Springer.

Hunger, Hermann, 1968. Babylonische und assyrische Kolophone. Neukirchen-Vluyn: Verlag Butzon \& Berker Kevalaer.

Jeyes, Ulla, 1989. Old Babylonian Extispicy. Omen Texts in the British Museum, Istanbul: Nederlands Instituut voor het Nabije Oosten/Netherlands Institute for the Near East. Leichty, Erle, 1964. The Colophon. In: Robert D. Biggs and John A. Brinkman, eds., Studies Presented to A. Leo Oppenheim. Chicago: Oriental Institute, 147-155. 
Melville, Duncan J., 2002. Weighing Stones in Ancient Mesopotamia. Historia Mathematica, 29, 1-12.

Neugebauer, Otto, 1934-1936. Serientexte in der babylonischen Mathematik. In: idem, Quellen und Studien zur Geschichte der Mathematik, Astronomie und Physik, B 3, 106114.

Neugebauer, Otto. 1935-1937, Mathematische Keilschrifttexte I-III. Berlin: Springer.

Neugebauer, Otto/Sachs, Abraham. J., 1945. Mathematical Cuneiform Texts, New Haven: American Oriental Society.

Powell, Marvin, 1982. Metrological Notes on the Esagila Tablet and Related Matters; Annexe II: Brick as Evidence for Metrology. Zeitschrift für Assyriologie und Vorderasiatische Archäologie, 72, 116-123.

Proust, Christine, 2005. A propos d'un prisme du Louvre: aspects de l'enseignement des mathématiques en Mésopotamie, SCIAMVS, 6, 3-32.

Proust, Christine, 2007. Tablettes mathématiques de Nippur. [= Varia Anatolica, XVIII]. Istanbul: IFEA, De Boccard.

Proust, Christine, 2008a., Quantifier et calculer: usages des nombres à Nippur, Revue d'histoire des mathematiques, 14, 143-209.

Proust, Christine ,2008b. Tablettes mathématiques de la collection Hilprecht. [= Texte und Materialen der Frau Professor Hilprecht Collection, 8]. Leipzig: Harrassowitz.

Proust, Christine, 2009a. Deux nouvelles tablettes mathématiques du Louvre: AO 9071 et AO 9072, Zeitschrift für Assyriologie, 99, 1-67.

Proust, Christine, 2009b. Numerical and Metrological Graphemes: from Cuneiform to Transliteration, Cuneiform Digital Library Journal 2009: 1: http://www.cdli.ucla.edu/pubs/cdlj/2009/cdlj2009_2001.html.

Proust, Christine, forthcoming-a. How to Interpret the Application of the Reverse Algorithm in some Mesopotamian Texts? In: Karine Chemla, ed., History of Mathematical Proof in Ancient Traditions. The other Evidence. Cambridge: Cambridge University Press.

Proust, Christine, forthcoming-b. A Tree-structured List in a Mathematical Series Text from Mesopotamia. In: Karine Chemla and J? Virbel, eds., Introduction to Textology via Scientific Writings.

Robson, Eleanor, 1997. Three Old Babylonian Methods for Dealing with "Pythagorean" Triangles. Journal of Cuneiform Studies, 49, 51-72.

Robson, Eleanor, 1999. Mesopotamian Mathematics, 2100-1600 BC. Technical Constants in Bureaucracy and Education, vol. XIV. Oxford: Clarendon Press.

Robson, Eleanor, 2001. The Tablet House: A Scribal School in Old Babylonian Nippur. Revue d'Assyriologie, 95, 39-66.

Robson, Eleanor, 2008. Mathematics in Ancient Iraq: A Social History. Princeton: Princeton University Press.

Scheil, Vincent, 1915. Notules: XII. les tables igi x gal-bi, etc. Revue d'Assyriologie,12, 195198.

Scheil, Vincent, 1938. Tablettes susiennes: exercices scolaires, calcul des surfaces. Revue d'assyriologie, 35, 92-103.

Thureau-Dangin, François, 1938. Textes Mathématiques Babyloniens. Leiden: Ex Oriente Lux. Tinney, Steve, 1996. The Nippur Lament. Royal Rhetoric and Divine Legitimation in the Reign of Išme-Dagan of Isin (1953-1935 BC). [= Occasional Publications of the Samuel Noah Kramer Fund, 16]. Philadelphia: University of Pennsylvania Museum. 
Tinney, Steve, 1999. On the Curricular Setting of Sumerian Literature. Iraq, 61, 159-172.

Veenhof, Klaas R., 1986. Cuneiform Archives. An Introduction. In: idem, Cuneiform Archives and Libraries. Papers Read at the 30ème Rencontre Assyriologique Internationale. Leiden. Nederlands Historisch-Archeologisch Instituut te Istanbul, 1-36.

Veldhuis, Niek, 1997. Elementary Education at Nippur, The Lists of Trees and Wooden Objects. Ph. D. Thesis, Groningen: University of Groningen.

Christine Proust

Université Paris Diderot, Laboratoire SPHERE

Case 7093

5 rue Thomas Mann

75205 PARIS CEDEX 13

France

Email: christine.proust@univ-paris-diderot.fr 